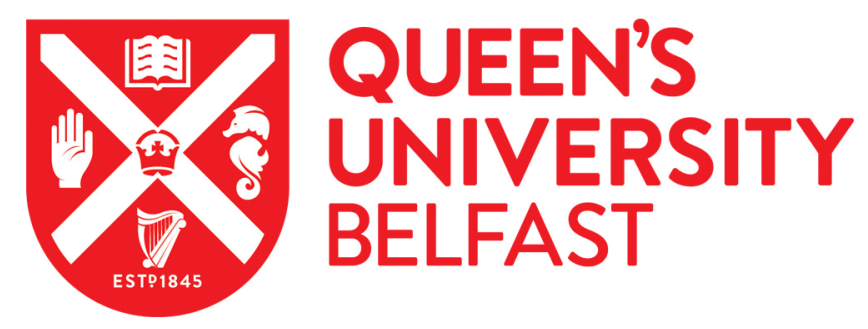

\title{
Refining the statistical parameters for constructing tree-ring chronologies using short-lived species: Alder (Alnus glutinosa Gaertn)
}

Barrett, M-T., Brown, D., \& Plunkett, G. (2019). Refining the statistical parameters for constructing tree-ring chronologies using short-lived species: Alder (Alnus glutinosa Gaertn). Dendrochronologia, 55, 16-24. https://doi.org/10.1016/j.dendro.2019.03.004

Published in:

Dendrochronologia

Document Version:

Peer reviewed version

Queen's University Belfast - Research Portal:

Link to publication record in Queen's University Belfast Research Portal

Publisher rights

Copyright 2019 Elsevier.

This manuscript is distributed under a Creative Commons Attribution-NonCommercial-NoDerivs License

(https://creativecommons.org/licenses/by-nc-nd/4.0/), which permits distribution and reproduction for non-commercial purposes, provided the author and source are cited

\section{General rights}

Copyright for the publications made accessible via the Queen's University Belfast Research Portal is retained by the author(s) and / or other copyright owners and it is a condition of accessing these publications that users recognise and abide by the legal requirements associated with these rights.

Take down policy

The Research Portal is Queen's institutional repository that provides access to Queen's research output. Every effort has been made to ensure that content in the Research Portal does not infringe any person's rights, or applicable UK laws. If you discover content in the Research Portal that you believe breaches copyright or violates any law, please contact openaccess@qub.ac.uk. 


\section{Refining the statistical parameters for constructing tree-ring chronologies using short- lived species: Alder (Alnus glutinosa Gaertn.)}

\section{Marie-Therese Barrett, David Brown, Gill Plunkett}

\section{Abstract}

The dendrochronological potential of short-lived species has had varying degrees of success in the past. Where there has been a level of success with short sequenced assemblages, the focus has been on visual comparisons, based on the occurrence of signature rings. Of vital importance to alder's ability to be cross-correlated is that it produces a significant amount of distinguishable signature rings. Between 2012 and 2013, a large artificial island (crannog) of medieval date was excavated at Drumclay, County Fermanagh, Northern Ireland, and revealed a site of significant longevity, dating from the 9th century AD to the Post-Medieval period. This excavation exposed a vast number of well-preserved waterlogged archaeological features, resulting in the retention of over 9,000 individual wood samples. Oak timbers were used scarcely in the construction of the crannog, with the dominant wood species identified during excavation being alder. While the oak timbers have proved successful in providing spot dates and indicating phases of activity, the full chronological potential of the wood assemblage lies in the ring patterns of the principal species, alder, particularly with respect to understanding construction phases and site evolution. Previous failures to build chronologies using alder have been attributed to the short-lived and site specific nature of the species. Here, we test whether the measurement of large numbers of samples from a single context within a single site overcomes the limitations posed by alder. We measured the ring-widths of 90 alder samples from archaeological features within the crannog's infrastructure to test if a robust context chronology could be built. The average ring sequence length ranged from 30 to 60 rings, with one timber extending to 108 rings. Visual correlations were used to aid ring pattern matching in conjunction with statistical correlation. We used radiocarbon wiggle-matching to test the robustness of our constructed chronology and to anchor it to an absolute timescale. Our results to date show that problems of autocorrelation can arise when long alder sequences (>100 rings) are used in conjunction with short sequences (30 to 60 rings). Establishing a rigorous protocol for sample selection has enabled us to develop a more statistically refined methodology that has produced $t$ values as high as 8.3. We show that in order to construct the best possible alder chronology, multiple ring patterns need to be examined from each context. We recommend examining short-lived assemblages on their own merits; the best approach in these cases is not to look for the longest sequences but instead to focus on the those from the mean sequence range. 


\section{Introduction}

The ability to obtain precise occupation dates for archaeological sites through tree-ring dating greatly improves the capacity of archaeologists to understand those sites in a wider context. In Ireland, crannogs (derived from the Irish crannóg, meaning timber structure) present an excellent opportunity to investigate settlement patterns in the early historic period. A crannog by its broadest definition is an artificial island or lakeside settlement, which in Ireland typically dates to the Early Medieval period, although differences in morphology and chronology are noted (Lynn, 1983; Crone, 1988; Edwards, 1990; O'Sullivan, 1998; Fredengren, 2002). These sites are of extreme importance to our understanding of the Early Medieval period, due to the high level of organic preservation from waterlogged sites. Only 29 (2.4\%) of the 1,200 known examples in Ireland have been excavated to any degree (O'Sullivan et al., 2013).

The chronology of Irish crannogs hinges primarily on dendrochronologically-dated structural timbers that provide spot dates from available and accessible timbers. While some of the dated timbers undoubtedly represent initial construction, others relate to any time during the lifecycle of that individual site. Arguably then, the use of unstratified timbers for dating purposes complicates the interpretation of crannogs chronologies, and individual dates do little to inform our grasp of when the sites were constructed and for how long they were occupied. With respect to Early Medieval settlement, Fitzpatrick (2009) argues that a fixation on establishing the construction dates of sites has been detrimental to a deeper understanding of how settlements developed in response to social change during their occupation.

Here we present the first extended tree-ring dating of an Early Medieval crannog in Ireland, that of Drumclay, Co. Fermanagh (Fig. 1). The excavation of Drumclay in 2012-2013 represents the only large scale investigation of a crannog under modern scientific conditions (Bermingham, 2014b), and afforded an opportunity to collect a large sample of structural timbers from throughout the site's occupancy. Although some oak timbers were recovered, the majority of the timbers used in the site derived from short-lived alder (Alnus glutinosa Gaertn), providing an occasion to construct the first short-lived tree-ring series for an Irish crannog. The dominance of an individual species and the large size of the assemblage presented two very favourable aspects for chronology construction, an achievement that would enable the site's construction, occupation and abandonment to be contextualised at a chronological resolution rarely achievable for a Medieval settlement. This paper outlines the development of a rigorous methodology for the construction of a robust alder tree-ring chronology, which we compare with a more limited oak chronology for the site. 
Alder is not an obvious choice for dendrochronological application for several reasons: it is a short lived species in comparison to oak, it can put on "false rings", and can exhibit stunted or supressed growth that at times make it all but impossible to measure the outer annual rings (Crone, 1988). Furthermore, research shows that the growth increment of alder is more susceptible to local environmental factors than to climate (Douda et al., 2009; Carvers and Crone, 2018). As a result, alder's dendrochronological application, particularly in the UK and Ireland, is still in its infancy. Nevertheless, its potential has been demonstrated by Crone $(1998 ; 2000 ; 2014)$, who investigated a number of crannogs in Scotland and one example in Ireland, and succeeded at producing an alder site chronology for the Scottish site Buiston. At Buiston, an oak chronology allowed the alder to be calibrated against the precisely-dated oak chronology from the site (Crone, 2000; 2014). At Cults Loch 3 and Oakbank, a number of small "floating" chronologies were constructed but an overall master chronology for the site was not attainable. Crone suggests that the failed cross-correlation of these "floating" chronologies may indicate the use of multiple sources of woodland (Crone, 2014). At Moynagh Lough, chronology construction was not possible due to the limited number of alder samples that were available from the site (Crone, 1988). In mainland Europe, the investigation of alder as a component of multi-species assemblages has been applied (Billamboz, 2008).

Further proof-of-concept for the use of short-sequenced timbers in dating archaeological sites in Ireland is shown by Daly (2014) who investigated alder and birch samples that rarely exceeded 30 years from two fishweirs in the Boarland Rock complex in the Fergus Estuary, Co. Clare (Daly, 2014). A "floating" chronology was successfully constructed for the alder timbers, and enabled the identification of building phases, repair and replacement of the two structures (Daly 2014; Daly et al., 2014). A birch chronology was not achieved, however, because the growth of birch was found to be complacent and the signatures were far less distinctive than they were in the alder (Daly, 2014).

\section{Site Description}

Drumclay crannog (SMR 211:061) was originally located in an inter-drumlin lake referred to as Knockalough, as can be seen in the first edition OS map (Fig. 1). This lake was subject to drainage in the 19th century and by 1873 it is described as a swamp (Wakeman, 1873). An eleven-month-long excavation revealed a wealth of well-preserved waterlogged deposits (Fig. 2). In terms of structural components, over 50 platforms and some 30 houses were identified and excavated. The site was initially dated by artefact typology and some wide-ranging radiocarbon dates that suggested a long history of occupation from the 7th century to the Post-Medieval period (Bermingham, 2014a). 
The site covered an area $26 \times 18 \mathrm{~m}$, and was $7 \mathrm{~m}$ deep, constructed mainly of alder timbers (Bermingham, 2014a). The material culture recovered during excavation included metal, pottery, stone, textile, leather, wood, bone, glass, antler, and amber, totalling over 5,500 artefacts. The site's rich repository of occupation debris accumulated over centuries in which major social and economic change occurred, including a period of shifting power structures and local territory disputes in the 9th century (Edwards, 1990; Simms, 1977), island-wide social reorganisation and the establishment of the first towns between the 9-11th centuries (Fitzpatrick, 2009; Kerr, 2007; Lyttleton and Monk, 2008), the knock-on effects of Anglo-Norman settlement in 12-13th centuries (Barrett and Graham, 1975), and a series of wars of the 16th century (Ó Domhnaill, 1946; Hayes-McCoy, 1990).

During the excavation of Drumclay crannog, approximately 9,000 individual pieces of timber were sampled for species identification; a full wood analysis has yet to be completed. Timbers were sampled by cutting approximately $10 \mathrm{~cm}$ thick cross-sections using a bow saw, which were then wrapped in cling film for storage (Bermingham, 2014a).

\section{Developing the methodology}

\section{Building the alder chronology}

We selected alder timbers based on a targeted visual identification from the lowest levels of the site for initial chronology construction. Initially, 73 samples from 14 contexts (here, 'context' refers to an archaeological feature) were analysed without reference to the stratigraphic position of the contexts, as recorded during excavation. This acted as a "blind test" to the sequencing of the contexts because successful tree ring analysis should be capable of producing unbiased tree-ring series without any prior archaeological information (cf. Bartholin, 1983).

We prepared the samples for tree-ring analysis using the razor blade method outlined by Brown (1991) and applied a fine, ground chalk to the prepared surface to highlight the ring boundaries. The ring sequences were counted and measured from pith (where present) to outer ring under a Nikon SMZ800 stereoscopic zoom microscope, on a travelling stage connected to a microcomputer that measures to a precision of $0.01 \mathrm{~mm}$. Bark was present on all samples, which facilitated the establishment of the felling date of each timber. TSAPWin software was used to record all measurements (Rinn, 2003). At this stage we excluded samples with less than 30 rings from further analysis. The majority of samples from this assemblage averaged between 30 and 60 rings, with the exception of $12(16 \%)$ ring sequences which did not exceed 30 rings and a single sample that exceeded 100 rings. We measured at least two and as many as four radii from each sample to ensure that any anomalies would be identified. Ring patterns from the radii of each sample were initially 
cross-dated against each other using CROS73 (Baillie and Pilcher, 1973). As the correlation algorithm was intended for longer tree-ring sequences (Hillam et al., 1987), cross-dating the short patterns inevitably produced some low $t$-values (ranging from 0.6 to $>12$ ) despite the sequences being from the same trees. Hence, we concluded that $t$-values could only be used as a guide to cross-matches, and we placed a greater emphasis on the visual correlations. We used the highest statistical correlations present but we did not at this stage set a critical or threshold value above which to accept correlations. Visual matching and the identification of signature rings was then utilised to verify the correlation.

Where two or more radii from a single sample yielded a significant visual correlation, they were pooled to produce a mean sample series. In 30 instances, failure to obtain a reliable correlation led to those samples being rejected from further analysis. Subsequently, by visually and statistically comparing the mean sample series for all timbers within a context in the same manner, we constructed a floating mean context chronology. We relied solely on the tree-ring curve comparisons and did not use the bark edge as a guide for assembling the context chronologies. We then cross-matched mean context chronologies with each other to establish a floating master site chronology. Finally, we considered the relative dates of each platform with respect to the archaeological sequence.

Of the 73 alder samples initially examined, 43 proved suitable for chronology construction based on visual matches. The samples contributing to the initial master chronology had a range of 34-108 growth rings, with an average of 45 rings. The mean context series correlated well visually and produced a site chronology that also respected the stratigraphic narrative set out by Bermingham (2014a). On the basis of these visual correlations, we constructed a 73-year long Master Chronology from 14 archaeological contexts from the lowest stratigraphic levels of the site (Fig. 3). The end dates of the timbers indicate felling dates spanning a period of 22 years.

\section{Anchoring the alder chronology}

Unlike oak, alder does not have a master chronology against which it can be absolutely dated. To anchor the Drumclay alder chronology to a calendrical timescale, we therefore applied $A M S{ }^{14} \mathrm{C}$ dating and wiggle-match modelling. We selected six timbers from platforms from the floating chronology and under laboratory conditions, we cleaned their surfaces to remove any possible contamination that may have occurred during the measurement and counting process. Using a scalpel, 5-year blocks of annual growth rings were extracted at known intervals for ${ }^{14} \mathrm{C}$ dating, and each dating sample was assigned a UB code. In total, 13 samples were submitted for dating to the 
${ }^{14} \mathrm{CHRONO}$ Centre, Queen's University Belfast (Table 1). The results were wiggle-match modelled with OxCal 4.2, using the Intcal13 calibration curve and the D_Sequence function (Bronk Ramsey et al., 2001; Bronk Ramsey, 2009; Reimer et al., 2013).

When the ${ }^{14} \mathrm{C}$ dates from the Drumclay alders were wiggle-matched with respect to their position in the initial chronology, the model failed, highlighting an issue with a series of five sequential samples. These five samples were from one individual timber (Q11677B), notably one of two unusually longlived timbers (108 years) in the chronology which had correlated with the shorter sequences with a $t$-value of 2.8. The poor agreement of the dates in the wiggle-match model strongly implies that the timber does not fit the chronology. Wiggle-match dating these five dates independently of the other ${ }^{14} \mathrm{C}$ dates yielded a successful model and produced a modelled felling date of $A D 750-790$ for this timber. Examination of the archaeological archive revealed that both this timber and Q11677A - a similarly long-lived alder with which Q11677B had a strong visual correlation - bore mortice joints of no obvious functional value in the context in which they had been found (Fig. 4). We determine that both timbers have been re-used. As Q11677B is evidently older than the rest of the sequence, we conclude that the mainly visual cross-correlation with the site chronology is the result of autocorrelation arising from the comparison of short sequences against longer series. We therefore removed the ring pattern from the Drumclay chronology, and revisited our criteria for sample inclusion.

\section{Refining the methodology}

To test if a more rigorous sample selection from a single archaeological context would affect the chronology, we selected a feature (platform 4720) with a large number of samples for analysis. As many as 19 alder samples were available from this context, including the two long-lived alders, Q11677A and Q11677B, that we infer to be re-used, older timbers. To avoid autocorrelation, we omitted the long patterns, and focused on the remaining seventeen timbers to test if a statistical filter would improve the quality of the chronology. A correlation threshold was implemented, allowing only samples producing an intra-correlation $t$-value of $>5$ for radii correlations and an intercorrelation $t$-value of $>3.5$ for sample correlations. This lower threshold for correlations between trees reflects the low $t$-values expected for short sequences (Hillam et al., 1987). Additionally, we also implemented a threshold of a minimum overlap of 35 rings for inter-correlations.

Seven samples were excluded, after measurements and ring counts established that they did not exceed 30 rings. In addition, we rejected a further five samples due to poor statistical correlation, despite good visual correlation, as their inability to pass the $3.5 t$-value threshold likely indicates that 
site-specific ecological influences are overshadowing the regional climate signal. A revised mean context series was constructed from the remaining five timbers (Fig. 5). These samples all correlated to a high standard visually, with an overlap of a minimum of 35 rings each and produced $t$-values as high as 8.3. We therefore conclude that it is necessary to apply stronger statistical filters, and that visual matching alone is not sufficient.

We then re-examined the samples from the other 13 contexts, and constructed a revised site chronology. The more stringent criteria resulted in four mean context series being excluded due to $t$ values $<3.5$, and a further four contexts because they were only represented by a single timber. Hence, the revised master chronology comprised six archaeological contexts. The four individual timbers were then cross-correlated against each of the six mean context series, as well as the Master Site Chronology. Of these, one (Context 4826) was accepted as it produced $t$-values $>3.5$ against the individual mean context series, and a $t$-value of 5.6 against the Master Site Chronology (with an overlap of 44 years). This allowed us then to construct a Master Site Chronology from seven contexts (Fig. 6).

With the exception of Q11677B, all ${ }^{14} \mathrm{C}$ dated timbers passed the more stringent selection process. We therefore re-ran the wiggle-match model with the remaining eight dates. Despite poor agreement for two samples (UBA-36809 and UBA-29911; discussed further below), the model was an overall success.

\section{Building the oak chronology}

Dendrochronological methods for oak chronologies at Queen's University Belfast in general follow those described by Baillie (1982) and English Heritage (1998). Thirty-three oak samples were examined from Drumclay crannog and were prepared and measured as described above. The treering series obtained for the samples were plotted onto graph paper to facilitate visual comparison. In addition, the cross-correlation algorithms CROS84 (Munro, 1984) and CROS73 (Baillie and Pilcher, 1973) were employed to search for positions where the tree-ring series were highly correlated. These positions were then checked visually using the plotted graph. The measured sequences were compared with regional and local site chronologies using a number of matching criteria (high $t$ values, replicated values against a range of chronologies at the same position, and satisfactory visual matching) to obtain calendar dates for the tree-ring sequences. Nineteen samples were successfully dated against the Belfast Oak Chronology. From these samples, four provided precise felling dates, seven samples provided a good estimated felling date range and eight samples provided a terminus post quem for felling (Fig. 7; Appendix 1). The remaining 14 samples were found to have ring 
patterns of less than 100 years, as well as problematic bands of rings, making them unsuitable for dendro-dating against the master oak chronology.

\section{Results and Discussion}

Our ring-width analysis of short-lived timbers from Drumclay crannog has succeeded in producing a 71-year-long chronology. Approximately $51 \%$ of alder timbers that we initially selected from the sample archive proved suitable for visual matching, others proving to be too short or irregular for reliable correlation. Through ${ }^{14} \mathrm{C}$-dating, however, we identified that visual matching alone presented a problem of auto-correlation when exceptionally long sequences were run against shorter series. We therefore determined that some degree of statistical matching is needed to differentiate ring patterns that are mainly climatically-responsive, and thus reduce the noise within the master tree-ring series. Introducing threshold $t$-values for acceptance of intra- and inter-sample correlations for this purpose resulted in a smaller dataset passing the criteria for inclusion in the chronology, but had the effect of yielding better and more robust correlations overall. Ultimately, only $32 \%$ of the processed samples were found suitable for statistical cross-correlation, demonstrating the need to acquire large numbers of samples in order to construct a reliable chronology.

The results of our wiggle-match modelling of the alder chronology suggest a date range of AD 800880 for the initial construction of Drumclay crannog (Fig. 8). This date is significantly later than that proposed on the basis of material culture and isolated ${ }^{14} \mathrm{C}$ dating evidence from the site (Bermingham 2014a). We note two samples (UBA-36809 and UBA-29911) that show poor agreement in the model. The samples derive from two unrelated timbers and from separate platforms (platforms 4720 and 4858, respectively) but their positions in the relative chronology overlaps by three years. Their ${ }^{14} \mathrm{C}$ dates therefore essentially replicate each other, and indicate that their age estimates - seemingly young with respect to the rest of the sequence - are not random outliers. We hypothesise that the age reversal is the result of intersecting the ${ }^{14} \mathrm{C}$ anomaly associated with the $A D$ 775 cosmogenic event. This anomaly was identified by Hogg et al. (2009) and was subsequently recognised in Japanese cedar (Miyake et al., 2012; 2013). A more recent study shows that it is present in 44 tree-ring series from both hemispheres (Büntgen et al., 2018). Further analyses are being undertaken to verify if the anomaly has indeed been detected in the Drumclay timbers, as this offers the prospect of precisely anchoring the alder chronology.

When we compare the alder series with the Drumclay oak chronology, the two data sets reveal similar results with respect to construction dates. The alder chronology implies that construction 
began in the period $A D 800-880$. The oak samples derive from contexts that are stratigraphically higher (i.e., later) than the alder chronology, and the first firm felling estimates - from those samples whose heartwood-sapwood boundaries survive - cluster around AD846 \pm 9 years. The two datasets strongly imply, therefore, a $9^{\text {th }}$ century $A D$ date for initial construction and occupation of the site.

The alder chronology not only provides a date for the earliest construction of the site, but allows us to view the relative chronological relationships between these archaeological contexts (Fig. 6). We can therefore reconstruct the evolution of the site on an annual basis. Our initial results reveal the following stages of construction and expansion.

1. The earliest archaeological deposit represented in this chronology is Context 4858. This context represents the lowest platform in the western area of the site, and was sitting on piles that were driven into the lake sediment (Birmingham, 2014a). This context and its subsequent relationship with the other contexts may be taken as the starting point (Year 1), representing the initial construction of the site.

2. The next platform (Context 4811) is a double layer of roundwoods and is stratigraphically above Context 4858. The alder chronology informs us that this platform was built a year later (Year 2) and can be interpreted as an attempt to consolidate the base of the site.

3. Next, Context 4826 - a threshold timber - was laid down five years later (Year 7). This context comprises the earliest evidence of a house or upstanding structure within the alder chronology and informs us that within at least six years of initial construction, a structure was built.

4. The following year (Year 8) we see roundwoods associated with a hearth deposit (Context 4616) from the same area (the western section of the site). This again suggests a continuous development and rate of construction. The same year we see the construction of Context 4648 , a double layered platform that supports House 8043 . This year represents the start of construction for this phase of occupation.

5. The following year (Year 9) another substantial platform (4720) was built. The dating of this platform again confirms that the site was intensively developed during its initial construction (Fig. 6).

6. The latest context to be resolved in this study was Context 3891, a platform containing a double layer of roundwoods in the northern part of the site (Fig. 9). This structure was built 21 years after the initial construction of the site. This area had become detached from the rest of the site in antiquity and had subsided, rendering its stratigraphic relationship to other features on the site unclear. The alder chronology allows this platform to be linked 
chronologically to the rest of the site (at Year 22), which would not be possible by any other means.

This Master Site Chronology represents merely seven contexts from the lowest levels of Drumclay crannog and provides us with far greater an insight into the construction rate of this site than would normally be possible on an Early Medieval occupation site. The chronology reveals that there was a continuous effort to consolidate the site during its initial construction. We see intensive construction at almost an annual level. Furthermore, it allows us to link a stratigraphically disjointed portion of the site (Context 3891 in the northern area) with the rest of the site in chronological terms.

While a full programme of species identification is ongoing, it is clear the primary species used for construction here is alder. This selection is not unique to Drumclay; for example, the wood assemblage from the Sroove crannog, Co. Sligo is dominated by alder (Fredengren et al., 2013) and alder similarly dominates in many Scottish examples (Crone, 2014). This selection has been interpreted as a logical selection of accessible timber, because alder is commonly found in boggy/marshy locations and at the edges of watercourses (Claessens et al., 2010; McVean, 1953), and would have been readily available for use in the lake environment.

\section{Conclusions}

On the basis of our experience with the alder timbers from Drumclay, we make several recommendations for the construction of short-lived tree ring series. We advise that only ring patterns of similar age spans be used to avoid problems of autocorrelation. We propose that measurements of multiple radii of a timber are needed to identify potential growth anomalies or problematic rings in a sample. While visual matching remains a valuable tool for correlating short ring patterns, we advocate the application of statistical correlation thresholds to reduce noise emanating from site-specific ecological factors and improve the robustness of the tree-ring series. Inevitably, such stringent selection criteria result in a large number of samples being rejected from analysis, and so very large assemblages of timbers are a requisite to the successful construction of a short-lived timber chronology.

Wiggle-match dating of the chronology has enabled the primary construction of the site to be dated to the $9^{\text {th }}$ century $A D$ and the sequence of subsequent site developments can now be traced at an annual resolution. As post-excavation of the archaeological archive progresses, this modelled 
timeline will greatly advance our understanding of this site and address the need for a more detailed chronological understanding of settlement in Early Medieval Ireland.

Our wiggle-match dating also highlights the presence of re-used timbers on the site and we recommend careful selection of ${ }^{14} \mathrm{C}$ samples through a short-lived chronology as a means of verifying the accuracy of the reconstructed sequence. We also note within our ${ }^{14} \mathrm{C}$ results the possible identification of the ${ }^{14} \mathrm{C}$ anomaly associated with the $A D 774 / 775$ cosmic event. The next stage of our research will be a confirmation of this event through a series a single ring sampling for radiocarbon dating and analysis, which would enable the Drumclay chronology to be dated to annual precision. The results presented here only represent a small percentage of what the site has to offer in terms of dendrochronological analysis, which will be fully published in due course.

\section{Acknowledgements}

This research was undertaken as part of a postgraduate studentship to Marie-Therese Barrett funded by the Department for the Economy. We acknowledge the Historic Environment Division of the Department for Communities, in particular Jacqueline McDowell, for allowing us access to the samples and site archives. Radiocarbon dates were kindly provided by the ${ }^{14} \mathrm{CHRONO}$ Centre, Queen's University Belfast.

\section{References}

Baillie, M. G. L., Pilcher, J. R., 1973. A simple cross-dating program for tree-ring research. Tree Ring Bulletin 33, 7-14.

Baillie, M. G. L., 1982. Tree-Ring Dating and Archaeology. Croom Helm. London, 274 pp.

Barrett, G. F., Graham, B. J., 1975. Some considerations concerning the dating and distribution of ring-forts in Ireland. Ulster Journal of Archaeology 38, 33-45.

Bartholin, T. S., 1983. The combined application of dendrochronology and wood anatomy, in: Eckstein, D., Wrobel, S., Aniol, R. W. (Eds.), Dendrochronology and Archaeology in Europe. Proc. of a workshop of the European Science Foundation. Hamburg, pp.79-92.

Bermingham, N., 2014a. Drumclay Crannóg: Preliminary Data Structure Report prepared by TVAS Ltd on behalf of the Northern Ireland Environment Agency. 1-159.

Bermingham, N., 2014b. Drumclay Crannog: A multi-generational settlement explored. Medieval Archaeology 58, 376-382. 
Billamboz, A., 2008. Dealing with heteroconnections and short tree-ring series at different levels of dating in the dendrochronology of the Southwest German pile-dwellings. Dendrochronologia 26, $145-55$.

Bronk Ramsey, C., van der Plicht, J., Weninger, B., 2001. 'Wiggle matching' radiocarbon dates. Radiocarbon 43, 381-389.

Bronk Ramsey, C., 2009. Bayesian analysis of radiocarbon dates. Radiocarbon 51.1, 337360.

Brown, D. M., 1991. Studies on Pinus sylvestris L. from Garry Bog. Co. Antrim. MSc Thesis, Queen's University Belfast.

Büntgen, U., Wacker, L., Galván, J. D., Arnold, S., Arseneault, D. , Baillie, M., Beer, J., Bernabei, M., Bleicher, N., Boswijk, G., Bräuning, A., Carrer, M., 13, Ljungqvist, F. C., Cherubini, P., Christl, M., Christie, D. A., Clark, P. W., Cook, E. R., D’Arrigo, R., Davi, N., Eggertsson, Ó., Esper, J., Fowler, A. M., Gedalof, Z., Gennaretti, F., Grießinger, J., Grissino-Mayer, H., Grudd, H., Gunnarson, B. E., Hantemirov, R., Herzig, F., Hessl, A., Heussner, K., Jull, A. J. T., Kukarskih, V., Kirdyanov, A., Kolář, T., Krusic, P. J., Kyncl, T., Lara, A., LeQuesne, C., Linderholm, H. W., Loader, N. J., Luckman, B., Miyake, F., Myglan, V. S., Nicolussi, K., Oppenheimer, C., Palmer, J., Panyushkina, I., Pederson, N., Rybníček, M., Schweingruber, F. H., Seim, A., Sigl, M., Churakova (Sidorova), O., Speer, J. H., Synal, H., Tegel, W., Treydte, K., Villalba, R., Wiles, G., Wilson, R., Winship, L. J., Wunder, J., Yang, B., Young, G. H.F., Tree rings reveal globally coherent signature of cosmogenic radiocarbon events in 774 and $993 \mathrm{CE}$. Nature Communications 9, DOI: 10.1038/s41467-018-06036-0.

Cavers, M.G., Crone, A., 2018. A Lake Dwelling in Its Landscape: Iron Age Settlement at Cults Loch, Castle Kennedy, Dumfries and Galloway. Oxbow Monographs, Oxford, 288 pp.

Claessens, H., Oosterbaan, A., Savill, P., Rondeux, A., 2010. A review of the characteristics of black alder (Alnus glutinosa (L.) Gaertn.) and their implications for silvicultural practices. Forestry 83.2,163175.

Crone, A., 1988. Dendrochronology and the study of crannogs. PhD Thesis, University of Sheffield.

Crone, A., 2000, The history of a Scottish Lowland Crannog: excavations at Buiston, Ayrshire 1989-90, AOC/STAR Monograph 4, Edinburgh.

Crone, A., 2014. Dendrochronological Studies of Alder (Alnus Glutinosa) on Scottish Crannogs. Journal of Wetland Archaeology 14.1, 22-33.

Daly, A., 2014. Fine-Tuned Chronology of Medieval Fishweirs on the Fergus Estuary, Co. Clare, Ireland. Journal of Wetland Archaeology 14, 6-21.

Daly, A., O'Sullivan, A., Sands, R., 2014. Chronology, Culture and Archaeology: Precision Chronology of Wetland Structures Using Tree-Ring Studies. Journal of Wetland Archaeology 14, 1-5.

Douda, J., Čejková, A., Douda, K., Kochánková, J., 2009. Development of alder carr after the abandonment of wet grasslands during the last 70 years. Annals of Forest Science 66 (7) DOI: 10.1051/forest/2009065. 
Edwards, N., 1990. The Archaeology of Early Medieval Ireland. London, 226 pp.

English Heritage., 1998. Dendrochronology: Guidelines on producing and interpreting dendrochronological dates. London.

FitzPatrick, E., 2009. Native Enclosed Settlement and the Problem of the Irish 'Ring-fort'. Medieval Archaeology 53, 271-307.

Fredengren, C., 2002. Crannogs: A Study of People's Interaction with Lakes, with Special Reference to Loch Gara in the North West of Ireland. Bray, 332 pp.

Fredengren, C., McClatchie, M., Stuijts, I., 2004. Connections and Distance: Investigating Social and Agricultural Issues Relating to Early Medieval Crannogs in Ireland. Environmental Archaeology 9.2, 173-179.

Hayes-McCoy, G. A., 1990. Irish Battles: A Military History of Ireland. Belfast, 326 pp.

Hillam, J., Morgan, R. A., Tyers, I., 1987. Sapwood estimates and the dating of short ring sequences, in: R.G.W. Ward (Eds.), Applications of tree-ring studies - current research in dendrochronology and related areas, British Archaeological Reports. International series 333. Oxford. pp. 165-85.

Hogg, A., Palmer, J., Boswijk, G., Reimer, P., Brown, D., 2009. Investigating the interhemispheric 14C offset in the 2st Millennium AD and assessment of laboratory bias and calibration errors. Radiocarbon 51.4, 1177-1186.

Kerr, T. R., 2007. Early Christian Settlement in North-West Ulster. British Archaeological Reports. Oxford.

Lynn, C., 1983. Some early Ringforts and Crannogs. Journal of Irish Archaeology 1, 47-57.

Lyttleton, J., Monk, M., 2008. Sites, social change and warfare in the second half of the first millennium AD: a reappraisal, in: Manning, C. (Eds.), From Ringforts to Fortified Houses: studies on castles and other monuments in honour of David Sweetman. Bray, pp. 17-19.

McVean, D. N., 1953. Alnus Glutinosa (L.) Gaertn. Journal of Ecology 41.2, 447-466.

Miyake, F., Kentaro, N., Kimiaki, M., Nakamura, T., 2012. A signature of cosmic-ray increase in AD 774-775 from tree rings in Japan. Nature 486, 240-242.

Miyake, F., Kimiaki, M., Nakamura, T., 2013. Another rapid event in the carbon-14 content of tree rings. Nature Communications 4, DOI: 10.1038/ncomms2783.

Munro, M. A. R., 1984. An improved algorithm for crossdating tree-ring series. Tree-Ring Bulletin 44, $17-27$.

Ó Domhnaill, S., 1946. Warfare in Sixteenth-Century Ireland. Irish Historical Studies 5, 2954.

O'Sullivan, A., 1998. The Archaeology of Lake Settlement in Ireland. Dublin, 236 pp. 
O'Sullivan, A., McCormick, F., Kerr, T., Harney, L., 2013. Early Medieval Ireland AD 4001100: The evidence from Archaeological Excavations. Dublin, 584 pp.

Reimer, P. J., Bard, E., Bayliss, A., Beck, J. W., Blackwell, P. G., Bronk Ramsey, C., Grootes, P. M., Guilderson, T. P., Haflidason, H., Hajdas, I., Hatt, C., Heaton, T. J., Hoffmann, D. L., Hogg, A. G., Hughen, K. A., Kaiser, K. F., Kromer, B., Manning, S. W., Niu, M., Reimer, R. W., Richards, D. A., Scott, E. M., Southon, J. R., Staff, R. A., Turney, C. S. M., van der Plicht, J., 2013. IntCal13 and Marine13 Radiocarbon Age Calibration Curves 050,000 Years cal BP. Radiocarbon 55.4, 1869-1887.

Rinn, F., 2003. Time series analysis and presentation software (TSAP-Win) user reference (version 0.53). RinnTech, Heidelberg, Germany.

Simms, K., 1977. The Medieval Kingdom of Lough Erne. Clogher Record 9.2, 126-141.

Wakeman, W. F., 1873. Observations on the principal crannogs of Fermanagh. The Journal of the Royal Historical and Archaeological Association of Ireland 2.2, 305-324.

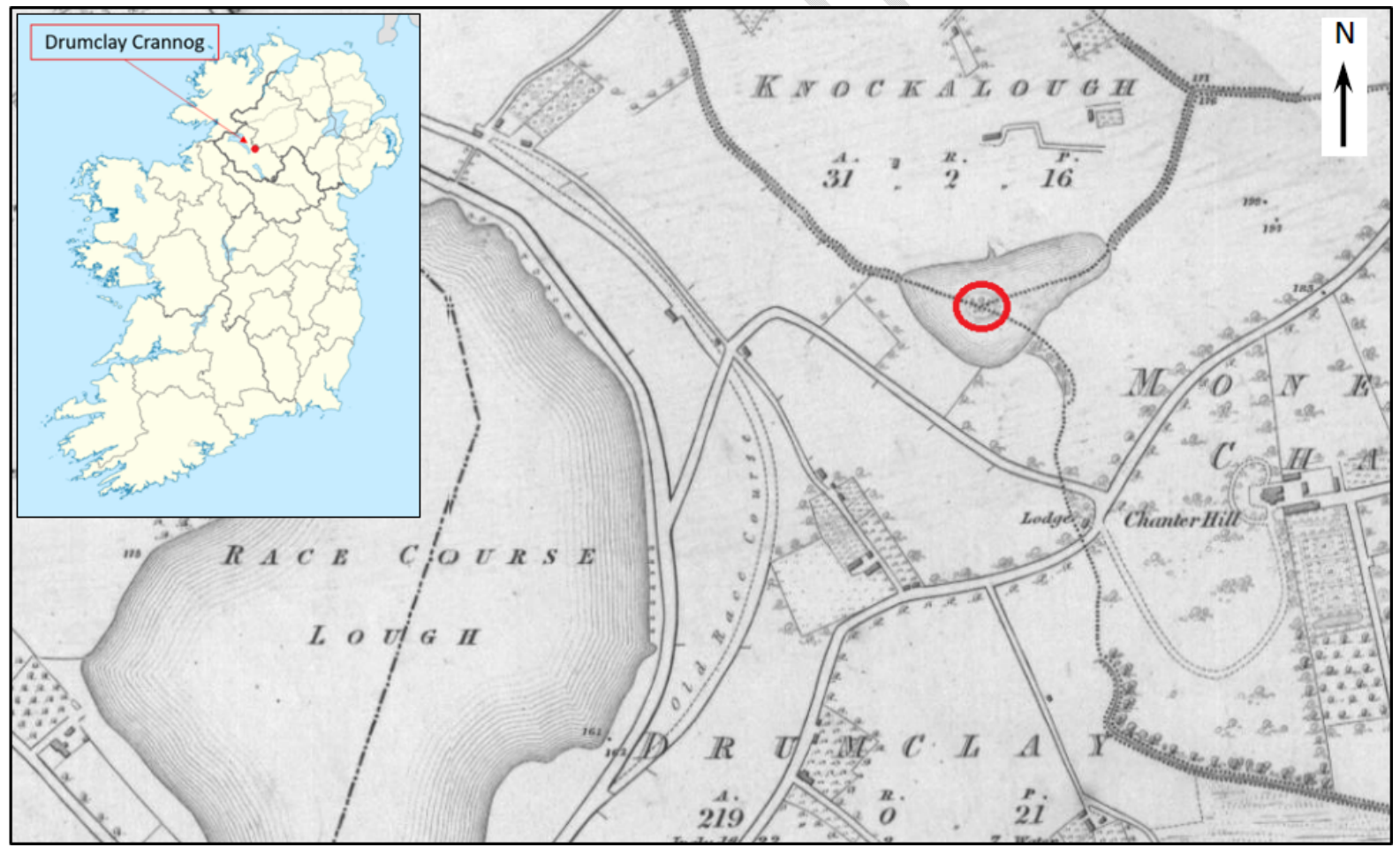

Fig. 1. Location map of Drumclay crannog. OS 6-inch map, $1^{\text {st }}$ edition 1835, showing the location of Drumclay crannog (indicated by the red circle). Image (C) Crown, Department for Communities. 


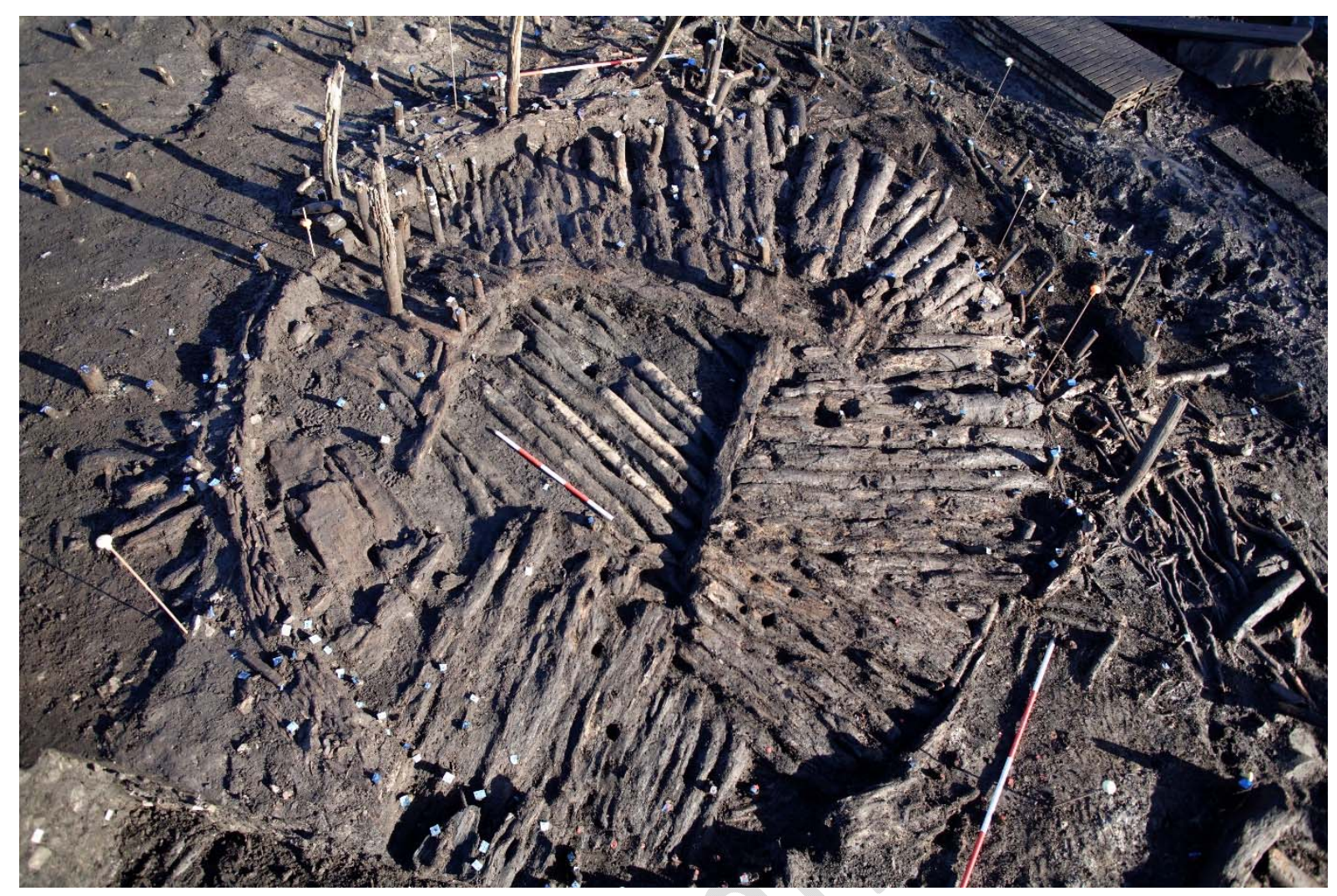

Fig. 2. Drumclay crannog during excavation. Image @ Crown, DfC Historic Environment Division.

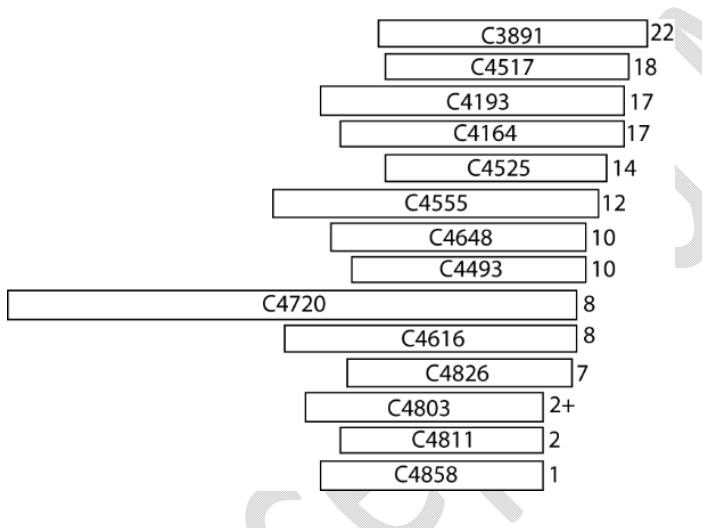

Fig. 3. Relative felling/construction dates for 14 contexts (context numbers indicated) from Drumclay crannog, correlated using the visual method. The numbers to the right indicate the relative felling/construction year. 


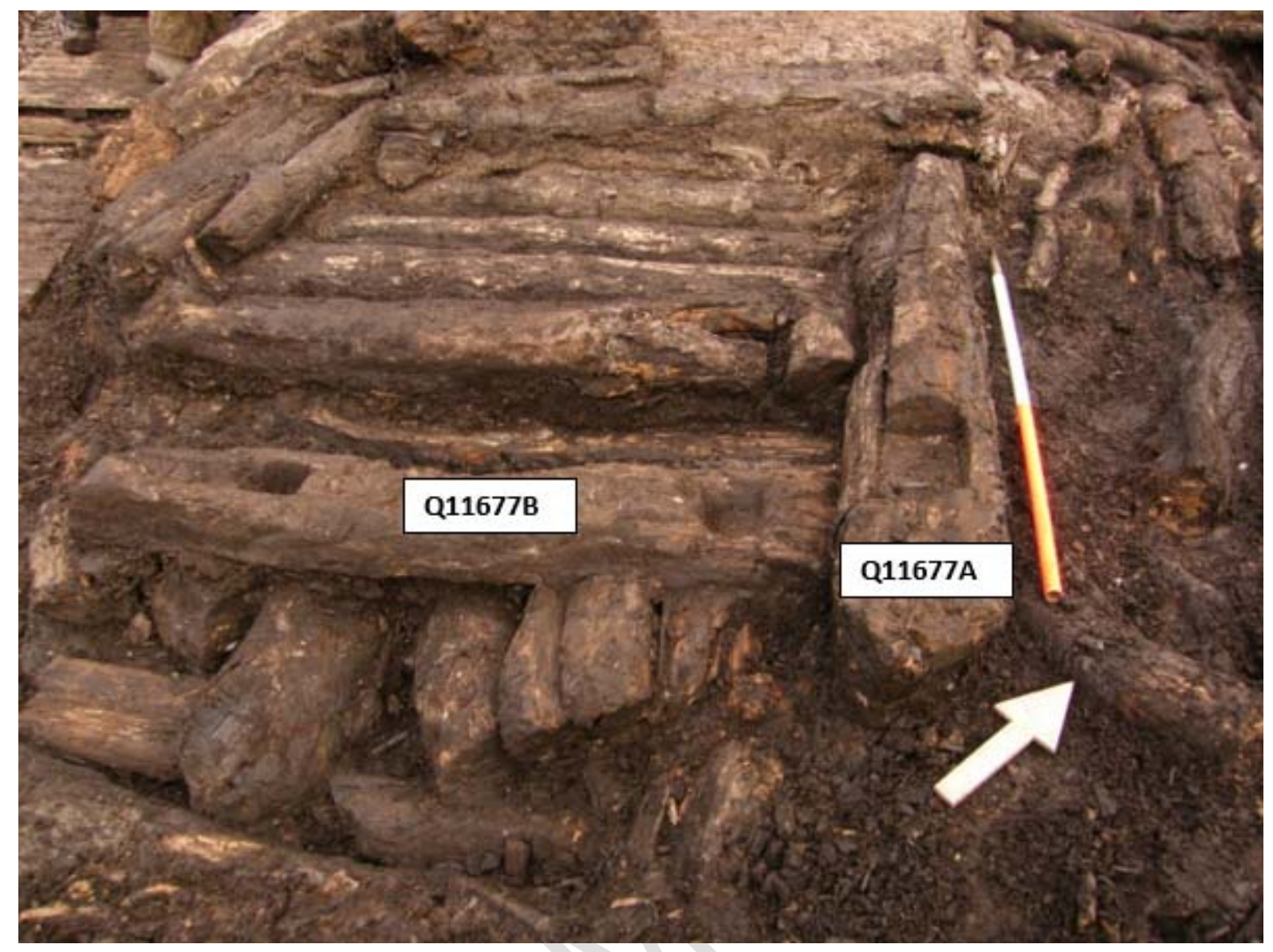

Fig. 4. View of platform 4720, showing timbers containing obsolete mortice joints (Q11677A and Q11677B labelled). The $14 C$ dates from Q11677B show that this timber is older than the rest of the structure, confirming that the timber is re-used. The arrow in the foreground of the picture is pointing north and the ranging rod measures $1 \mathrm{~m}$. Image (C) Crown DfC Historic Environment Division. 


\section{Drumclay Crannog}

Platform 4720

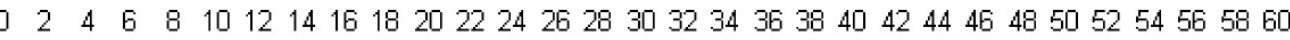
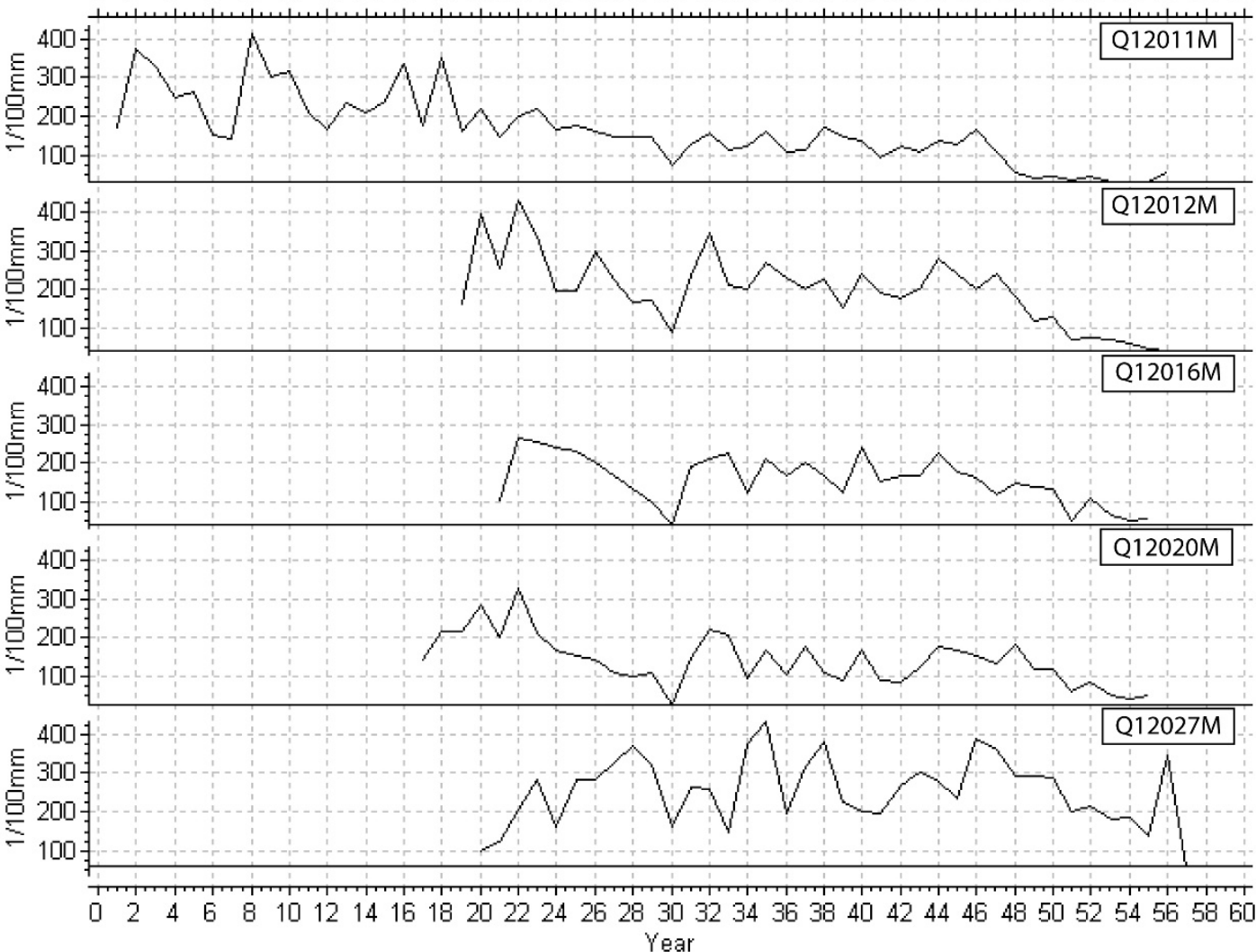

Fig. 5. Ring width patterns of five timbers from platform 4720, whose positions are relative to the first ring of the oldest tree.

\section{Context 3891}

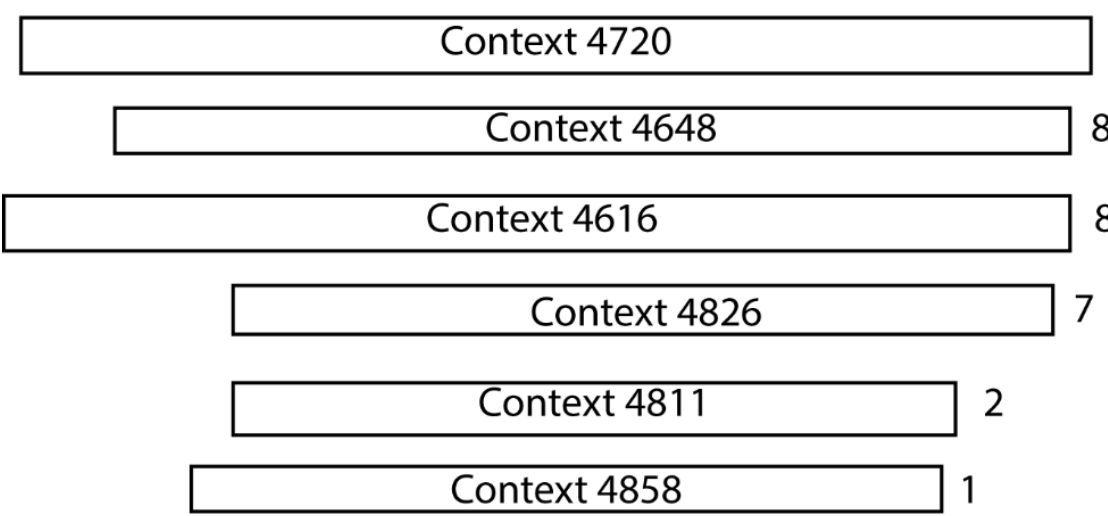

Fig. 6. Relative felling/construction dates for seven contexts from Drumclay crannog correlated using statistical matching with $t$-values $>3.5$. Numbers to the right denote the relative felling/construction years. 
Drumclay Oak

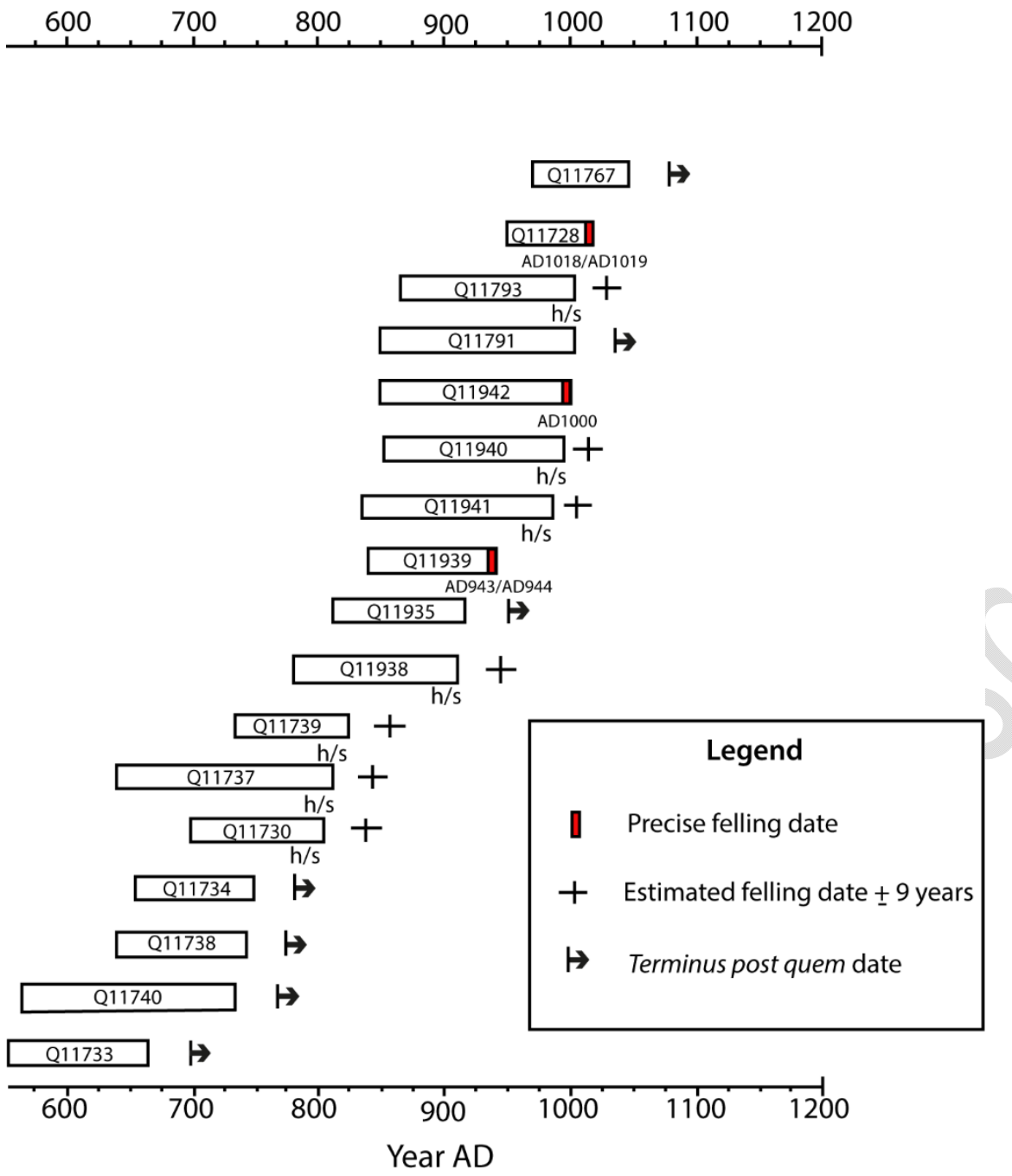

Fig. 7. Early Medieval Oak Chronology from Drumclay crannog. Felling phases at c. $A D 820, A D 940$ 's, and c. $A D 1000$ are evident. 


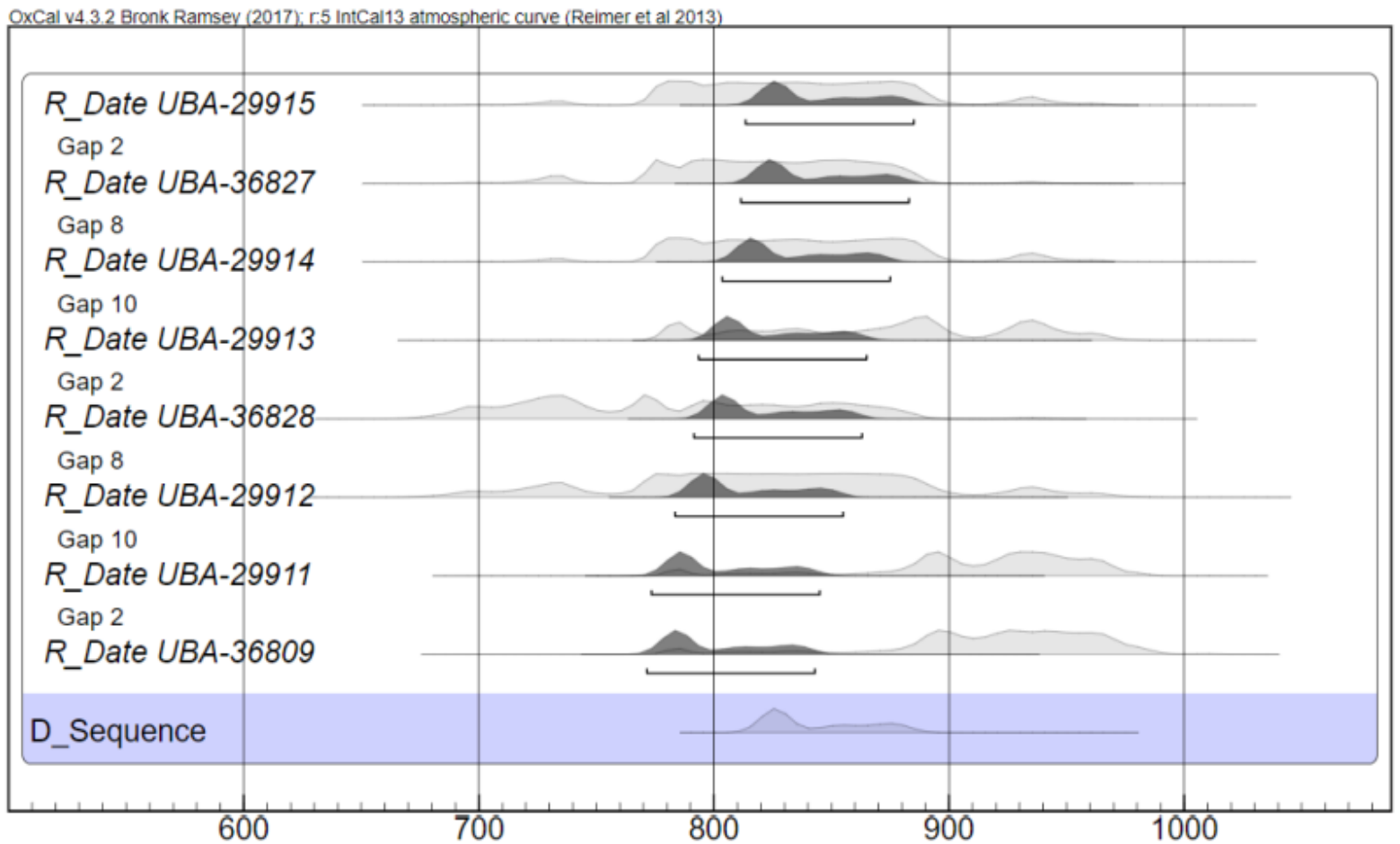

Fig. 8. 14C Wiggle-match model for eight samples from Drumclay using the D_Sequence in OxCal 4.2 (Bronk Ramsey et al., 2001).

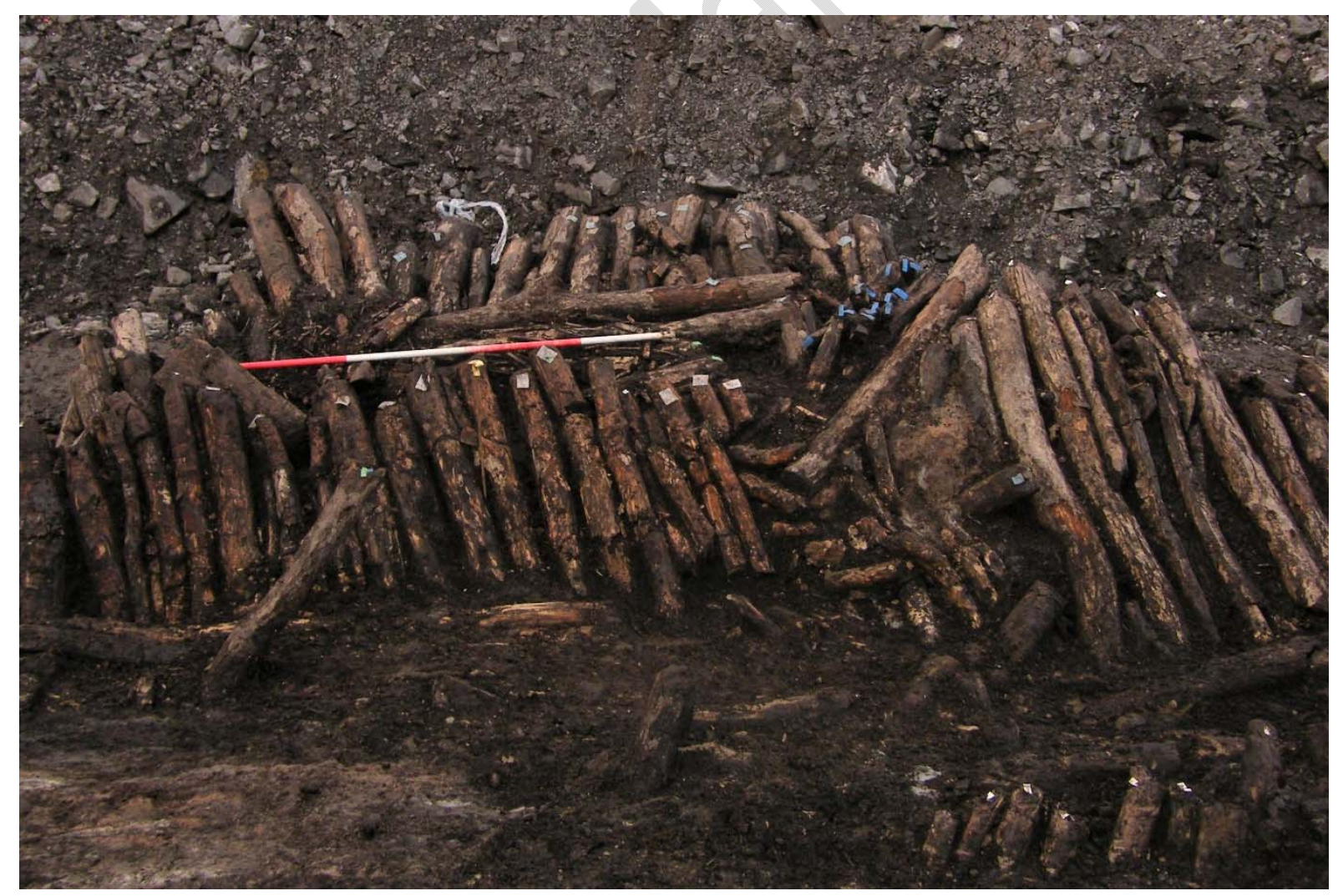

Fig. 9. Floor deposits in Northern subsided area C3891, C4164, C4094, looking NW. Image (c) Crown, DfC Historic Environment Division. 
Table 1: Comparison between modelled and unmodelled age ranges (95\% confidence level) for Drumclay ${ }^{14} \mathrm{C}$ samples (minus dates from Q11677B re-used timber). Ring numbers are relative to the start of the floating datum.

\begin{tabular}{|c|l|l|l|l|l|l|}
\hline $\begin{array}{c}\text { UBA } \\
\text { number }\end{array}$ & $\begin{array}{c}\text { Rings } \\
\text { sampled }\end{array}$ & $\begin{array}{c}\text { Mid- } \\
\text { point }\end{array}$ & ${ }^{14}$ C Age & \pm & $\begin{array}{c}\text { Unmodelled } \\
\text { calibrated dates } \\
\text { AD }\end{array}$ & $\begin{array}{c}\text { Modelled calibrated } \\
\text { dates AD }\end{array}$ \\
\hline UBA-29915 & $55-59$ & 57 & 1185 & 28 & $729-944$ & $813-885$ \\
\hline UBA-36827 & $53-57$ & 55 & 1203 & 24 & $725-890$ & $811-883$ \\
\hline UBA-29914 & $45-49$ & 47 & 1183 & 28 & $769-946$ & $803-875$ \\
\hline UBA-29913 & $35-39$ & 37 & 1157 & 24 & $775-967$ & $793-865$ \\
\hline UBA-36828 & $33-37$ & 35 & 1232 & 33 & $688-882$ & $791-863$ \\
\hline UBA-29912 & $25-29$ & 27 & 1198 & 43 & $689-962$ & $783-855$ \\
\hline UBA-29911 & $15-19$ & 17 & 1137 & 23 & $777-982$ & $773-845$ \\
\hline UBA-36809 & $13-17$ & 15 & 1129 & 27 & $778-989$ & $771-843$ \\
\hline
\end{tabular}

Appendix 1: Details of the nineteen oak samples dated from Drumclay crannog. $h / s$ refers to the heartwood/sapwood boundary

\begin{tabular}{|l|l|l|l|l|l|}
\hline $\begin{array}{l}\text { QUB } \\
\text { number }\end{array}$ & $\begin{array}{l}\text { Number } \\
\text { of rings }\end{array}$ & $\begin{array}{l}\text { Sapwood rings } \\
\text { present }\end{array}$ & Start date & End date & $\begin{array}{l}\text { Felling date or } \\
\text { best estimated } \\
\text { felling date range }\end{array}$ \\
\hline Q11728 & 69 & 23 complete & AD 950 & AD 1018 & AD 1018/AD 1019 \\
\hline Q11730 & 108 & h/s present & AD 699 & AD 806 & AD 838 \pm 9 years \\
\hline Q11733 & 112 & No h/s & AD 554 & AD 665 & After AD 697 \\
\hline Q11734 & 95 & No h/s & AD 656 & AD 750 & After AD 782 \\
\hline Q11737 & 172 & h/s present & AD 640 & AD 811 & AD 843 \pm 9 years \\
\hline Q11738 & 107 & No h/s & AD 638 & AD 744 & After AD 776 \\
\hline Q11739 & 91 & h/s present & AD 735 & AD 825 & AD 857 \pm 9 years \\
\hline Q11740 & 171 & No h/s & AD 566 & AD 736 & After AD 768 \\
\hline Q11767 & 78 & No h/s & AD 970 & AD 1047 & After AD 1079 \\
\hline Q11791 & 156 & No h/s & AD 849 & AD 1004 & After AD 1036 \\
\hline Q11793 & 141 & 9 not complete & AD 865 & AD 1005 & AD 1028 \pm 9 years \\
\hline Q11794 & 74 & No h/s & AD 1519 & AD 1592 & After AD 1624 \\
\hline Q11847 & 96 & 18 complete & AD 1385 & AD 1480 & Spring AD 1481 \\
\hline
\end{tabular}




\begin{tabular}{|l|l|l|l|l|l|}
\hline Q11935 & 109 & No sapwood & AD 811 & AD 919 & After AD 951 \\
\hline Q11938 & 132 & h/s boundary & AD 781 & AD 912 & AD 944 \pm 9 years \\
\hline Q11939 & 105 & 26 complete & AD 839 & AD 943 & AD 943/AD 944 \\
\hline Q11940 & 146 & 15 not complete & AD 852 & AD 997 & AD 1014 \pm 9 years \\
\hline Q11941 & 153 & 15 not complete & AD 836 & AD 988 & AD 1005 \pm 9 years \\
\hline Q11942 & 151 & 30 complete & AD 850 & AD 1000 & Spring AD 1000 \\
\hline
\end{tabular}

